\title{
Underinvestment, Debt Financing, and Long-term Supplier Relations
}

\author{
Venkat Subramaniam
}

A. B. Freeman School of Business

Tulane University

\begin{abstract}
Prior studies have documented that in firm-supplier relations where the firm makes an investment up-front, the profits are exposed to expropriation by the supplier, and results in underinvestment. We analyze such a firm-supplier relation in a bargaining framework, and show that the bargaining power of the firm is positively related to the resale value of its investment, and negatively related to the product market surplus generated by the investment. In this scenario, debt financing is advantageous to the firm since it shields some wealth away from the supplier. We also demonstrate that allowing the firm to issue debt and retire equity subsequent to the investment decision mitigates the underinvestment problem. This result obtains even when the debtholders are forced to participate in the negotiations. However, this efficiency property of debt is lost if the investment is made by the supplier and not by the firm.
\end{abstract}




\section{Introduction}

The opportunism problem in bilateral relations, that arises when one party has a bargaining advantage over the other, has been studied in different contexts in the literature (Williamson, 1975; Grout, 1984; Helper and Levine, 1992). We analyze this problem by considering a firm that makes an up-front investment, and enters into a longterm relation with a single supplier who supplies a specialized input. Once the investment is sunk, the supplier has little incentive to stay with any prior agreements, and may bargain for a greater share of the value of the relationship by threatening to delay or stop production. ${ }^{1}$ Although the firm may sue for breach of contract, hold-up is still possible because lawsuits are not fully effective when legal costs are high, or when there are legal delays. There is substantial empirical evidence that even the potential for a hold-up has adverse implications for equityholder value of the firm. ${ }^{2}$

In this paper, we assume that if the supplier decides to go on "strike," a bargaining phase ensues, and production occurs only if an agreement is reached between the two parties about how to share the product market proceeds. An arrangement where the firm makes the investment, but also rationally anticipates that the final proceeds are likely to be shared with the supplier, leads to an inefficient investment decision. Observe that the efficient level of investment would be to invest until the marginal surplus is zero. However, since the entire surplus does not go to the firm, it will only invest up to the level where the marginal surplus that accrues to it is zero. This results in underinvestment by the firm.

We show that the underinvestment described above is mitigated if the firm is allowed to issue debt and retire equity. Since debt is a senior claim, by using debt, the final surplus that has to be shared with the supplier is reduced by the face value of debt. The equityholders of the firm do not lose in this process because they receive the market 
value of the debt up-front, and so effectively reduce their own equity investment. Also, since the debt is priced correctly, there is no wealth transfer from the debtholders to the equityholders. Therefore, issuing debt reduces the supplier's payoff. However, we show that debt is also costly to the equityholders, since it reduces their status quo payoff during bargaining, and also increases the expected bankruptcy costs. We demonstrate that the first cost is bounded above due to limited liability, and the second (bankruptcy cost) can be lowered by increasing investment. Thus, allowing the firm to use debt also enhances the firm's incentives to invest. These results obtain even when the debtholders are forced to participate in the negotiations. Finally, we also show that this efficiency property of debt is lost if the up-front investment is made by the supplier and not by the firm. In this case, increasing the firm's debt only exacerbates underinvestment because, with debt the divisible surplus and the supplier's return are further reduced.

Our paper is related to prior work which shows that market exchanges that involve relationship-specific investments may be sometimes governed more efficiently using long-term contracts (Joskow, 1985; Hermalin and Katz, 1993; Edlin and Reichelstein, 1996), or vertical integration (Kliendorfer and Knieps, 1982; Wiggins, 1990). In particular, we extend the literature in labor economics on the problem of a supplier holding up the firm. In this context, some relevant examples include Baldwin (1983), Grout (1984), Bronars and Deere (1991), Helper and Levine (1992), Dasgupta and Sengupta (1993), and Perotti and Spier (1993). Our paper is also related to the research pioneered by Brander and Lewis (1986) on the commitment role of debt under imperfect competition. ${ }^{3}$

Hermalin and Katz (1993) and Edlin and Reichelstein (1996) show that if legal enforcement of specific performance is costless and information is symmetric, then longterm contracts solve the underinvestment problem. However, debt financing is a viable alternative solution given that verification of state or performance is costly (Milgrom and 
Roberts, 1992:301), and legal enforcement is costly either due to direct costs or due to legal delays (Tirole, 1990:30). Further, it is also possible that there is asymmetric information ex ante, since firms may be privately informed about their investment, particularly about the opportunity costs of the managerial and technical personnel committed to the project. When information is not symmetric at the time of the initial bargaining, Hermalin and Katz show that contracts are not efficient, and judicial modification is necessary to restore efficiency.

The underinvestment problem that arises when contracting parties cannot make binding commitments was first modeled by Baldwin (1983), and Grout (1984). They show that when workers cannot commit to not holding up the firm for higher wage demands, the rational response of the firm is to lower its investment, or to maintain inefficient plant in production in order to discourage those demands. In this context, Bronars and Deere (1991) argue that firms can prevent the formation of a labor union by issuing debt. Since a union can only extract revenues that accrue to the firm after all liabilities are paid, by issuing debt, the equityholders can commit some of the revenues away from the union. ${ }^{4}$ In a similar vein, Perotti and Spier (1993) show that firms can extract wage concessions from their workers by issuing debt and retiring equity. In their model, the debt for equity swap occurs if profits are not enough to fully pay the promised wages of the workers, and before a new investment is undertaken. This enables the firm to use the debt overhang problem (Myers, 1977; Berkovitch and Kim, 1990) to credibly threaten its workers that it will forego the profitable investment if the workers do not agree to a wage reduction. ${ }^{5}$ Thus in both papers, debt enables the firm to reduce the surplus accruing to the labor union.

Our paper differs from Bronars and Deere (1991) in that, they use debt as a solution to the hold-up problem, but ignore the firm's investment decision and the underinvestment problem. In their model, even riskless debt would be adequate, since it 
shields wealth away from the supplier. We model the firm's investment decision, and show that riskless debt transfers only a fixed surplus away from the supplier, but does not affect the firm's marginal return on investment. Hence, investment remains inefficient. On the other hand, if debt were risky, the loan given to the equityholders is discounted from its face value due to the possibility of default and due to any associated bankruptcy costs. We then show that increasing investment reduces this discount on risky debt and increases firm value. Thus the use of risky debt not only mitigates the hold-up problem but also mitigates the underinvestment problem.

Our analysis also differs from the one in Perotti and Spier (1993). In their paper, debt is issued before investment is made, while in ours it is issued after the investment is made. This difference in timing is critical because, in their paper, debt helps the firm in its threat to underinvest, which in turn forces the workers to offer wage concessions. In our paper, debt overhang does not arise because investment is already in place. Here, debt is optimal because it shields some wealth away from the supplier. Further, we show that when the firm is allowed to issue debt and retire equity subsequent to the investment decision, the investment chosen up-front is higher, and closer to the efficient level. Thus in their model, debt causes underinvestment which is used to expropriate the supplier, while in our model debt solves the underinvestment that arises because of supplier opportunism.

Finally, our paper is also related to Helper and Levine (1992), who analyze a firm's choice between arm's length sourcing from several suppliers and a long-term relation with a single supplier. They argue that firms with large product market rents (monopolies) prefer arm's length sourcing in order to prevent being held-up by a sole supplier who wants to share those rents, while firms with little product market rents prefer long-term relations in order to reap rents from cooperation. In our paper, we show that even those firms that have large product market rents could enter into a long-term 
relation with a single supplier, but can use debt to protect these rents from expropriation. We further demonstrate that using risky debt mitigates the underinvestment problem that arises in long-term supplier relations.

The remainder of this paper is organized as follows. In section 2 we present the model and assumptions about the bargaining game. In section 3 we describe the underinvestment problem, and the debt solution. In Section 4, we consider the case where the investment is made by the supplier and not by the firm, and demonstrate that debt financing by the firm actually exacerbates underinvestment, and is no longer efficient. Section 5 contains concluding comments and a discussion of the costs associated with vertical integration, an alternative solution to the hold-up and underinvestment problems.

\section{Model and Assumptions}

\subsection{Basic Framework}

We model the firm-supplier arrangement in a one period, 2-date, but multi-stage framework. In the first stage on date 0 , an investment $\mathrm{I}$ is made by the firm towards real assets that support production. This investment may be viewed as enhancing the quality of the input, and hence that of the output produced by the firm. After the investment is made, the firm makes a financial decision in the second stage. In this stage, the firm may issue debt and retire equity, where the debt (if issued) matures on date 1 and is repaid from the profits after the revenues are generated. $D(\geq 0)$ denotes the face value of the firm's debt. Once the investment and financial decisions are made, production of the input and the subsequent output takes place in the third stage. Production occurs over the period, and at the end of the period (on date 1) the firm sells the final product and generates its revenues. 
In the product market, on date 1 , the firm faces a stochastic demand that generates revenues of $R(I, \omega)$ where $\omega$ is the random variable that represents the price risk. The lower bound of this random variable $\omega$ is normalized to zero. The probability density function of $\omega$ is $f(\omega)$ and its support is on $[0, \Omega]$. The revenues $\mathrm{R}(\mathrm{I}, \omega)$, are net of production and input procurement costs but not net of the investment of the firm, and may be viewed as the state dependent product market surplus that is generated at the end of the period. $\mathrm{R}_{1}$ and $\mathrm{R}_{2}$ represent partial derivatives w.r.t. I and $\omega$, respectively. Since $\mathrm{R}$ does not contain the cost of the investment, but reflects the benefits from the improvement in the quality of the input, $R_{1}>0$. The state variable $\omega$ is arranged such that higher realizations of $\omega$ correspond to higher revenues: $R_{2}>0$. We assume that $R(I, \omega)=0$ whenever $I$ or $\omega$ is zero. To ensure an internal optimum for investment choice, we assume that $R_{11}<0$. When $\omega=\omega^{*}$, the firm is just able to pay off its debt obligations. In other words, $\omega^{*} \in[0, \Omega]$ is such that

$$
\mathrm{R}\left(\mathrm{I}, \omega^{*}\right)=\mathrm{D} \text {. }
$$

Since $R_{2}(I, \omega)>0$, the firm is bankrupt in all states $\omega$, where, $\omega<\omega^{*}$. Let $p=\operatorname{Pr}\left\{\omega: \omega \geq \omega^{*}\right\}$ be the probability that the firm is solvent. Of course, both $\omega^{*}$ and this probability are dependent on the level of investment and on the level of debt. Differentiating equation (1) w.r.t. D we get

$$
\frac{\mathrm{d} \omega^{*}}{\mathrm{dD}}=\frac{1}{\mathrm{R}_{2}\left(\omega^{*}\right)}>0 \text {. }
$$

and differentiating it w.r.t I we get

$$
\frac{\mathrm{d} \omega^{*}}{\mathrm{dI}}=-\frac{\mathrm{R}_{1}(\mathrm{I}, \omega)}{\mathrm{R}_{2}\left(\omega^{*}\right)}<0 .
$$

The two inequalities above capture the intuitive idea that the bankruptcy states and therefore the probability of bankruptcy are increasing in D, and decreasing in I. 
We also assume that bankruptcy is costly in that there are two types of dead weight costs associated with financial distress. First is the legal and administrative costs of a formal bankruptcy process, or the bargaining costs of firms involved in a private workout. The second is the indirect cost of bankruptcy that arises from consumers and suppliers being reluctant to do business with a firm in financial distress, and the competitors taking predatory actions that hasten the firm's demise. Since both the intensity of bargaining and the indirect costs of bankruptcy are related to the amount by which the revenues fall short of the liabilities, we assume that the bankruptcy costs are proportional to the size of this shortfall. For each level of debt, we denote the expected bankruptcy costs of the firm by 6

$$
\mathrm{C}\left(\omega^{*}\right)=\int_{0}^{\omega^{*}} \mathrm{c}[\mathrm{D}-\mathrm{R}(\mathrm{I}, \omega)] \mathrm{f}(\omega) \mathrm{d} \omega \quad \text { where } 0<\mathrm{c}<1 .
$$

and using (1)

$$
\frac{\partial \mathrm{C}\left(\omega^{*}\right)}{\partial \mathrm{D}}=\mathrm{c} \int_{0}^{\omega^{*}} \mathrm{f}(\omega) \mathrm{d} \omega>0
$$

The expected cost is increasing in debt since both the probability and the size of the default are increasing in debt. All agents are risk neutral and the risk-free rate is assumed to be zero without loss of generality.

Let B represent the market value of the firm's debt.

$$
B=\int_{0}^{\omega^{*}} R(I, \omega) f(\omega) d \omega+\int_{\omega^{*}}^{\Omega} D f(\omega) d \omega-C\left(\omega^{*}\right)
$$

For an unlevered firm, we denote the product market surplus accruing at the end of the production period by $\mathrm{J}_{0}$.

$$
J_{0}=\int_{0}^{\Omega} R(I, \omega) f(\omega) d \omega
$$

For a levered firm the surplus that accrues to the firm is what remains after the debt obligations are paid, and for a given face value D, we denote that amount by J(I,D)

$$
\begin{aligned}
& \mathrm{J}(\mathrm{I}, \mathrm{D})=\int_{\omega^{*}}^{\Omega}\{\mathrm{R}(\mathrm{I}, \omega)-\mathrm{D}\} \mathrm{f}(\omega) \mathrm{d} \omega \\
\Rightarrow & \mathrm{J}(\mathrm{I}, \mathrm{D})=\mathrm{J}_{0}-\left[\mathrm{B}+\mathrm{C}\left(\omega^{*}\right)\right]
\end{aligned}
$$




\subsection{The Bargaining Stage}

During the production stage, we assume that the supplier can halt production and hold out for a fraction of the product market surplus $\mathrm{J}_{0}$. Since the cooperation of the supplier is necessary for production, the end product is produced if and only if there is agreement in the bargaining phase. ${ }^{7}$ In order that we may focus on the impact of financing choice on the bargaining power of the firm, we assume away any informational asymmetry problems between the firm and the supplier that would confound this analysis. Hence, during bargaining, both the firm and the supplier are assumed to be informed completely and symmetrically about the distribution of the demand uncertainty variable and about the expected product market surplus. Without loss of generality, we assume that if there is no agreement in the bargaining phase then the supplier's payoff (status quo) is zero, and that of the equityholders is $\mathrm{T}$, the proceeds from the resale of the investment net of any liabilities. We assume that the investment has a resale value of $\rho I$, where $0 \leq \rho \leq 1$. If $\rho$ is small, i.e., close to zero, then we say that the asset specificity of the investment is high. If $\rho$ is large (close to 1 ) then the asset specificity is low. Thus

$$
\mathrm{T}=\operatorname{Max}\{0, \rho \mathrm{I}-\mathrm{D}\} .
$$

In summary, the sequence of the various stages in this model are as follows. First the firm decides on its investment level. Once the investment is in place the firm has the option of issuing debt and retiring equity. This stage determines the face value of the firm's debt obligations that are due after the revenues are generated. This is followed by the bargaining phase, where the rule for the sharing of the final product market surplus between the firm and the supplier is determined. If there is no agreement in the bargaining phase, then the two parties receive their respective status quo payoffs. If there is agreement, then production takes place over the length of the period. On date 1, the products are sold, revenues are generated, and the surplus is shared after all liabilities are 
paid. We use backward induction and first determine the Nash equilibrium for the bargaining game, which gives us the payoffs to the firm and the supplier for a given level of debt and investment. Next we solve for the level of debt, and then investment, taking into consideration their impact on the equityholder value. The solution is restricted to be subgame perfect in the sense of Selten (1975).

The equilibrium solution for the firm's bargained surplus is implicitly a function of the level of debt and investment chosen by the firm. Since the bargaining game is a full information game, the two parties will reach an agreement and there exists a unique subgame perfect equilibrium (Rubinstein, 1982; Sutton, 1986). The Nash solution to the bargaining stage proposes that the firm and the supplier each receive their status quo (disagreement) payoff plus one-half of the additional surplus that is generated from cooperation. ${ }^{8}$ Hence, for a firm with face value of debt $\mathrm{D}$, and investment $\mathrm{I}$, the payoff to the equityholders is $(1 / 2)[\mathrm{J}(\mathrm{I}, \mathrm{D})-\mathrm{T}]+\mathrm{T}$. Thus, incorporating their financial decision, the equityholders maximize,

$$
\mathrm{E}(\mathrm{I}, \mathrm{D})=(1 / 2)[\mathrm{J}(\mathrm{I}, \mathrm{D})-\mathrm{T}]+\mathrm{T}+\mathrm{B}-\mathrm{I}
$$

and the supplier maximizes $\quad \mathrm{S}=(1 / 2)[\mathrm{J}(\mathrm{I}, \mathrm{D})-\mathrm{T}]$

From (10) and (11), if the firm is unlevered, the equityholders' payoff is $(1 / 2)\left[\mathrm{J}_{0}+\right.$ $\rho I$. As would be expected, the value accruing to the firm is increasing in $\rho$, the recoverable component of its investment. As $\rho$ increases, the firm's status quo position is bolstered and hence its bargained surplus is higher. Also by rewriting the payoff to measure the fraction of the total surplus $\mathrm{J}_{0}$ that accrues to the firm, we find that this fraction is $(1 / 2)\left(1+\rho \mathrm{I} / \mathrm{J}_{0}\right)$. Thus the fraction accruing to the firm is larger if the size of the product market surplus $\mathrm{J}_{0}$ relative to the level of investment $\mathrm{I}$ is smaller. This tells us that if the firm operates in an environment that is very competitive, i.e., an environment where large positive NPV projects are not available, then the firm's bargaining power visa-vis its supplier is larger. This is because the firm has little product market rents at risk 
and is thus less concerned about the possibility of the supplier trying to expropriate those rents. On the other hand, if the surplus $\mathrm{J}_{0}$ is large relative to $\mathrm{I}$, then the firm stands to lose a lot due to hold-up, and so the bargaining power of the firm is smaller. Hence, in this case, the firm will be reluctant to enter into a long-term relation with a single supplier, since that increases the potential for hold-up. This analysis is consistent with the argument in Helper and Levine (1992) that firms which operate in competitive markets will prefer to enter into long-term contracts with single suppliers, while firms that have high product market power will prefer arm's length sourcing from several suppliers.

Similar results are true even when the firm is levered. From (11), for a levered firm, the payoff to the equityholders is

$$
(1 / 2)[\mathrm{J}(\mathrm{I}, \mathrm{D})-\mathrm{T}]+\mathrm{T} .
$$

To see how this payoff changes with debt, consider first the case where $D<\rho$ I. In this case, upon disagreement, the equityholders receive the payoff ( $\rho \mathrm{I}-\mathrm{D})$ from liquidating the investment. This amount is strictly decreasing in $\mathrm{D}$, for all $\mathrm{D}<\rho \mathrm{I}$. Thus, increasing debt not only increases the bankruptcy costs, but also reduces the firm's status quo payoff, which adversely affects the firm's bargaining position. On the other hand, if D is sufficiently large, then $\mathrm{T}=0$ due to the limited liability of shareholders. Now any further increase in D will not reduce the status quo payoff or the firm's bargaining power, but will increase the expected bankruptcy costs. In what follows, we show that despite these costs, debt is advantageous to the firm. We also show that allowing the firm to issue debt and retire equity, increases efficiency by mitigating the underinvestment problem.

\section{Underinvestment Problem and the Optimal Financing Choice}

In this section, we first show that if the firm is not allowed to issue debt and retire equity, the supplier's propensity to hold-up the firm creates an inefficiency in the investment choice of the firm. We then demonstrate that if the firm is allowed to engage 
in a debt for equity swap then the underinvestment problem is mitigated. Also, for simplicity, we consider only the case where the liquidation value of the investment is zero, i.e., $\rho=0.9$

\subsection{The Underinvestment Problem in an Unlevered Firm}

For any firm, the efficient level of investment would be to invest until the marginal gains to the firm from a further increase in investment is zero. However, since the end-period surplus has to be shared with the supplier, the firm will only invest up to that level where the marginal surplus that accrues to it is zero. This results in the firm underinvesting relative to the efficient level defined below. Consider an unlevered firm. Since $\rho=0$, and $\mathrm{D}=0$, we have $\mathrm{B}=0$ and $\mathrm{T}=0$, and therefore the Nash solution is that both the firm and the supplier receive $(1 / 2) \mathbf{J}_{0}$. Thus equityholders maximize $(1 / 2) \mathrm{J}_{0}-\mathrm{I}$.

Proposition 1: The level of investment selected by the equityholders of an unlevered firm is strictly lower than that which maximizes the total end-period surplus.

Proof: For an unlevered firm, ignoring any supplier interaction, the objective for investment choice is the maximization of the end-period surplus, $\underset{I}{\operatorname{Max}}\left(\mathrm{J}_{0}-\mathrm{I}\right)$.

Let $\mathrm{I}^{*}$ be this optimal level of investment. Then $\mathrm{I}^{*}$ satisfies the condition below, and is our benchmark for the efficient level of investment.

$$
\frac{\partial \mathrm{J}_{0}}{\partial \mathrm{I}}-1=0
$$

However, if we incorporate the firm's interaction with its supplier, the equityholders' objective is

$$
\operatorname{Max}_{I}(1 / 2) J_{0}-I
$$

and if $\mathrm{I}^{* *}$ is the optimal investment for this maximization problem, then $\mathrm{I}^{* *}$ satisfies the condition

$$
\text { (1/ 2) } \frac{\partial \mathrm{J}_{0}}{\partial \mathrm{I}}-1=0
$$

$$
\text { A comparison of (14) and (16) reveals that } \mathrm{I}^{* *}<\mathrm{I}^{*} . \quad\left\{\text { Note: } \frac{\partial^{2} \mathrm{~J}_{0}}{\partial \mathrm{I}^{2}}<0\right\}
$$




\subsection{The Optimal Financing Choice}

We now demonstrate how debt affects the equityholder value in two conflicting ways. Since the bargaining is over the division of the end-period surplus $\mathrm{J}_{0}$, any action that would transfer a part of this surplus away from the end of the period to a point in time where sharing of the surplus does not occur, would be optimal to the firm. In other words, an optimal action by the firm will be one that will lower the divisible surplus but not the overall total amount that accrues to it. Issuing debt and retiring equity enables the firm to achieve this. Recall from (9) that by issuing debt and retiring equity the divisible surplus decreases from $J_{0}$ to $J(I, D)$. Although debt reduces the total surplus, the equityholders are not adversely affected since they receive the loan B, and are able to capture some of the surplus up-front. Further, since the debtholders operate under full information, the loan is correctly priced and there is no wealth transfer from the debtholders to the equityholders. Therefore, the loss in value is solely to the supplier. However, increasing debt is also costly to the equityholders because of the associated increase in bankruptcy and financial distress costs. Below we show that despite the bankruptcy costs, the firm is still able to use some debt to enhance its equityholder value.

Proposition 2: For any investment opportunity $J_{0}$, it is optimal for the equityholders to issue debt and retire equity subsequent to the investment decision.

Proof: Since $\rho=0$ (and so $\mathrm{T}=0$ ), the equityholders' maximization problem for debt is

$$
\operatorname{Max}_{\mathrm{D}}(1 / 2) \mathrm{J}(\mathrm{I}, \mathrm{D})+\mathrm{B}-\mathrm{I}
$$

and the first derivative of the equityholders' objective w.r.t. D is

$$
\left.(1 / 2)\left[-c \int_{0}^{\omega^{*}} f(\omega) d \omega\right)+\int_{\omega^{*}}^{\Omega} f(\omega) d \omega\right]
$$

Thus the optimal level of debt is just a trade-off of the bankruptcy cost of debt (the first term) against the benefit of increased product market surplus that debt shields away from the supplier (the second term). To see that a positive level of debt is optimal despite the 
cost, consider $\mathrm{D}=0$. Now, bankruptcy never occurs i.e., $\omega^{*}=0$, and so the first term in (17) is zero, while the second term is always positive. Therefore, D > 0 is unambiguously optimal.

Proposition 3: For any given investment opportunity $J_{0}$, the investment made by the firm is higher if the firm is allowed to issue debt and retire equity.

Proof: See the Appendix.

Investment increases with debt because of two distinct reasons. First, with debt the surplus that is shared between the firm and the supplier is reduced, but the equityholders capture the value up-front through the debt for equity exchange. Their return is further magnified by increasing investment because, investment increases the market value of the loan received by them (by lowering the probability of default). Thus allowing the use of risky debt, increases the firm's incentives to invest. ${ }^{10}$ The second reason arises due to the existence of bankruptcy costs. Although debt is associated with bankruptcy costs, proposition 2 shows that a positive level of debt is still optimal to the firm. Hence, any action that reduces the negative aspect of debt further increases the firm's optimal debt. Increasing investment is one such action. Additional investment reduces the expected bankruptcy costs and increases the firm's debt capacity, which improves equityholder value.

The result that debt may mitigate the underinvestment problem is in contrast to Myers (1977). The difference between our two results is due to the difference in the cause of the underinvestment in the two models. In Myers (1977), investment is made after the debt is issued, so firms underinvest since the shareholders do not capture the returns from investment in all states. On the other hand, in our paper, since investment is made before debt is issued, the loan is correctly priced to reflect all the returns on the investment, and so there is no debt overhang problem. Further, we show that when the 
firm is allowed to issue debt and retire equity subsequent to the investment decision, the investment chosen up-front is higher and closer to the efficient level.

In our model, we consider only the bankruptcy costs of debt and ignore other costs that arise due to well-known conflicts between capital suppliers and the firm. One such cost that is especially relevant to our model is due to the risk-shifting problem. Brander and Lewis (1986) show that when the demand for the product is stochastic, as in our model, it may be optimal for the shareholders to over-produce relative to what the bondholders prefer. With overproduction, if the state of nature is such that demand is high, then the shareholders receive large payoffs, if not, their payoffs are bounded below due to limited liability. Since the ex ante cost due to the firm's inability to commit to a production level is proportional to the debt level, which is similar to the bankruptcy cost in our model, our propositions can be extended to include this cost, and the results would be robust to the risk-shifting problem.

In a multi-period model, Hart and Moore (1994) address the problem where the firm could threaten to suboptimally liquidate unless the debt is renegotiated. Berglof and von Thadden (1994) address the other side of the same problem, where the debtholders can threaten to withhold credit for the future periods, and force liquidation unless the terms are renegotiated in their favor. In our one-period model, since there are no future periods where the debtholders can withhold funds, the latter problem does not arise. The firm and the supplier can however band together, and threaten to liquidate unless the face value of debt is reduced. This is equivalent to including the debtholders in the bargaining process, and imposing the additional constraint that the value accruing to them cannot exceed the promised face value. Here, any face value $D>\operatorname{Max}\left\{\rho \mathrm{I},(1 / 2) \mathrm{J}_{0}\right\}$ would be renegotiated down to $\operatorname{Max}\left\{\rho \mathrm{I},(1 / 2) \mathrm{J}_{0}\right\}$, because the threat by the firm-supplier alliance to liquidate would be credible. However, for small levels of debt $\left(D<\operatorname{Max}\left\{\rho \mathrm{I},(1 / 2) \mathrm{J}_{0}\right\}\right)$, 
the equilibrium where the bondholders offer no concessions is subgame perfect, and propositions 2 and 3 still obtain for some $\mathrm{D}$ such that $0<\mathrm{D}<\operatorname{Max}\left\{\rho \mathrm{I},(1 / 2) \mathrm{J}_{0}\right\} .{ }^{11}, 12$

The model has several empirical implications that are easy to test. Proposition 2 argues that firms that have long-term relations with their suppliers tend to have a higher proportion of debt in their capital structure. In the context of labor supply, the same implication may also be extended to firms that expect to face unionization by their workers. Direct evidence for this hypothesis in the labor market setting is found in Bronars and Deere (1991), and Garvey and Gaston (1995). They find that firms that have a higher probability of unionization have larger debt ratios. Garvey and Gaston find that this result obtains even after controlling for the endogeniety of wages, and the simultaneity of wages and debt. In their cross-sectional analysis of firms, Bronars and Deere estimate that a $10 \%$ increase in the probability of unionization is associated with a $12 \%$ increase in debt ratios.

Another empirical implication is in proposition 3 which argues that a firm's investment is positively related to its debt level, particularly for a firm that maintains long-term relations with its supplier. Although a direct analysis of investment choices and debt ratios of firms that are involved in long-term supplier relations has not been undertaken, evidence of a strong positive relation between firms' debt and their investment is documented in Harris (1994). ${ }^{13}$ Finally, in section 2.2, we show that firms that have large market power, i.e., firms with significant product market rents have lower bargaining power vis-a-vis their suppliers, and hence we expect those firms to be more levered than firms in competitive environments. Acs, Isberg, and Levy (1993) empirically analyze the relation between market power and financing choice of firms in manufacturing industries. Measuring market concentration with different indices such as the Herfindahl index and the 4-firm concentration ratio, they find that debt is positively related to the degree of market concentration, directly supporting our predictions. 


\section{Relationship-Specific Investment by the Supplier}

In this section we analyze the case where the investment, I, is made by the supplier instead of by the firm. Here, once the investment is sunk, the incentives for hold-up arise from the firm and not from the supplier. In what follows, we demonstrate that our earlier result that the firm can mitigate the underinvestment problem by issuing debt and retiring equity, depends critically on which of the parties, the firm or the supplier, makes the investment.

The sequence of decisions and the relevant decisionmakers in this section are identical to those in the previous sections but with the exception that investment here is made by the supplier and not by the firm. So, in the first stage the supplier makes a relationship-specific investment I, which is followed by the firm's choice of D. The bargaining stage is subsequent to these two decisions because, the firm now has little incentive to adhere to any prior agreements about sharing of the product market proceeds. We first solve for the optimal amount of debt chosen by the firm for a given level of investment by the supplier, we then solve for the optimal investment by the supplier who anticipates correctly the firm's incentives to choose debt in the subsequent stage.

Proposition 4: The level of investment made by the supplier is lower when the firm is allowed to issue debt and retire equity after the supplier's investment decision.

Proof: See the Appendix.

The proposition shows that even when the supplier makes the investment, the expected bankruptcy costs are lower and the market value of debt is higher with additional up-front investment. However, these effects are detrimental to the supplier because they increase the level of debt that the firm would select, which only reduces the supplier's share of the joint surplus. Hence, the supplier will lower its investment because its returns from investment are further diminished. Therefore, debt financing has 
the efficiency property of mitigating underinvestment only when the party that is making the investment is also the one that has access to the debt instrument.

The above result extends the view in Shleifer and Summers (1988) that restructurings (e.g., takeovers and leveraged buyouts) may harm stakeholders such as workers and suppliers through abrogated contracts. Thus, some of the gains to shareholders in restructurings may just be wealth transfers from other stakeholders of the firm, and not increases in efficiency. ${ }^{14}$ Supportive anecdotal evidence is in the success of Safeway Stores and TWA in renegotiating wage contracts with their workers after an LBO. There is further evidence in Baker and Wruck (1989) that after large leverage increasing recapitalizations, firms are able to extract concessions even from other input suppliers. ${ }^{15}$ Finally, there is also evidence in Schiller (1987) that some labor unions now demand contracts which stipulate that a firm cannot reorganize without the union's approval. This suggests that in a world with leveraged restructurings, workers and suppliers are ex ante concerned about their relationship-specific capital, and the reliability of implicit contracts.

\section{Conclusion}

Prior studies (Baldwin, 1983; Grout, 1984) have documented that in firm-supplier relations where the firm makes an investment up-front, the firm's profits are exposed to expropriation by the supplier, and results in underinvestment by the firm. We argue that allowing the firm to issue debt and retire equity subsequent to making the investment, mitigates the underinvestment problem. Debt is advantageous to the firm because it is only the equityholders who receive the loan up-front while the debt is repaid out of the end-period surplus, of which the supplier is also a stakeholder. Thus, debt financing enables the firm to shelter some of the surplus away from the supplier. However, debt also imposes two costs on the equityholders of the firm - it reduces their status quo payoff 
during the bargaining process, and increases the expected bankruptcy costs. We show that the first cost is bounded above due to limited liability, and the second cost (bankruptcy cost) may be lowered by increasing investment. Therefore, allowing the firm to use debt enhances the firm's incentives to invest. These results obtain even when the debtholders are forced to participate in the negotiations.

An alternative solution to the hold-up and the associated underinvestment problem is vertical integration with the supplier. Although the acquisition of complementary assets may be desirable to economize on the transaction costs, there are several other costs that arise due to vertical integration. For instance, if only a portion of the supplier's assets are required for production, a complete vertical integration will result in additional costs of administering and controlling unrelated businesses (Berger and Ofek, 1995). Also, independent organizations provide market based incentives that are lost under vertical integration (Bradley, Desai, and Kim, 1988; Williamson, 1985). Even from a managerial incentives perspective, expansions may be costly. Since stock value of an integrated firm is only a weak signal of the performance of any one divisional manager, stock based compensation is less efficient in integrated firms (Aron, 1991). Finally, if the supplier's assets are specialized, valuing these assets for acquisition may be a risky venture for the firm. This is further complicated if the supplier has liabilities that are hidden during the valuation process. ${ }^{16}$

Of course, our discussion is not intended to convey that vertical integration is always inferior to long-term relations with independent suppliers. Prior studies by Williamson (1975), Riordan (1989), and Wiggins (1990) show that one of the key advantages of vertical integration is that it facilitates a superior flow of information between the two partners. In Riordan (1989), integration is beneficial because it enables the firm to better observe the input costs. Wiggins (1990) constructs a model were he justifies why information improves under integration. He shows that when the firm and 
the supplier are separate, and when there is information asymmetry about cost and demand shocks, value is dissipated because either the firm's production level does not optimally reflect the cost shocks, or the supplier's production level does not reflect the demand shocks. In an integrated firm, on the other hand, when compensation of all divisional managers is tied to overall firm performance, the cost and demand shocks are revealed to all parties and are optimally incorporated in output. In our simplified model, vertical integration is handicapped because we ignore its informational advantages by assuming symmetric information between the firm and the supplier about input costs and downstream demand. Our aim is simply to illustrate that vertical integration need not be the only solution to opportunism; under certain financing conditions long-term relations between independently managed firms and suppliers can be efficiently sustained.

\section{Appendix}

Proof of Proposition 3: Suppose the firm is not allowed to undertake a debt for equity swap, and so remains fully equity financed, then the optimal investment is given by

$$
\operatorname{Max}_{I}(1 / 2) \mathbf{J}_{0}-\mathbf{I} \text {. }
$$

If $\mathrm{I}_{0}$ is the optimum investment for this all-equity case, then it satisfies the condition:

$$
\frac{\partial \mathrm{J}_{0}}{\partial \mathrm{I}}-2=0
$$

If the firm is allowed to use risky debt, then the optimal level of investment, $\mathrm{I}_{\mathrm{D}}$, of the equityholders is given by: $\quad \operatorname{Max}_{\mathrm{I}}(1 / 2) \mathrm{J}(\mathrm{I}, \mathrm{D})+\mathrm{B}-\mathrm{I}$.

Since, $\mathrm{J}(\mathrm{I}, \mathrm{D})=\mathrm{J}_{0}-\mathrm{B}-\mathrm{C}\left(\omega^{*}\right), \mathrm{I}_{\mathrm{D}}$ satisfies the condition

$$
\frac{\partial \mathrm{J}_{0}}{\partial \mathrm{I}}+\frac{\partial\left(\mathrm{B}-\mathrm{C}\left(\omega^{*}\right)\right)}{\partial \mathrm{I}}-2=0
$$

The fact that $I_{D}>I_{0}$ is established by substituting $I_{0}$ in (A1) and observing that 


$$
\frac{\partial\left(\mathrm{B}-\mathrm{C}\left(\omega^{*}\right)\right)}{\partial \mathrm{I}}>0 \quad \text { using (4) and (6). }
$$

Proof of Proposition 4: When the supplier makes the investment, for an unlevered firm the Nash solution to the bargaining stage gives the equityholders of the firm

$$
\begin{array}{ll} 
& \mathrm{E}(\mathrm{I})=(1 / 2) \mathrm{J}_{0}, \\
\text { and allocates } & \mathrm{S}(\mathrm{I})=(1 / 2) \mathrm{J}_{0}-\mathrm{I}, \text { to the supplier. } \\
\text { For a levered firm } & \mathrm{E}(\mathrm{I}, \mathrm{D})=(1 / 2) \mathrm{J}(\mathrm{I}, \mathrm{D})+\mathrm{B} \\
\text { and } & \mathrm{S}(\mathrm{I}, \mathrm{D})=(1 / 2) \mathrm{J}(\mathrm{I}, \mathrm{D})-\mathrm{I}, \quad \text { respectively. }
\end{array}
$$

The optimal debt is chosen with the following objective

$$
\underset{D}{\operatorname{Max}} \mathrm{E}=\operatorname{Max}_{\mathrm{D}}(1 / 2) \mathrm{J}(\mathrm{I}, \mathrm{D})+\mathrm{B}
$$

and the first derivative of the equityholders' objective w.r.t. D is

$$
\left.(1 / 2)\left[-c \int_{0}^{\omega^{*}} f(\omega) d \omega\right)+\int_{\omega^{*}}^{\Omega} f(\omega) d \omega\right]
$$

$\Rightarrow \quad$ From arguments identical to those in proposition 2, D > 0 is optimal.

Let $\mathrm{D}(\mathrm{I})$ and $\mathrm{B}(\mathrm{I})$ be the optimal face value and market values of debt, respectively, in the firm for a given level of I. Then the supplier selects I to

$$
\operatorname{Max}_{I} S=\operatorname{Max}_{I}(1 / 2) J_{0}(I)-(1 / 2)\left[B+C\left(\omega^{*}\right)\right]-I
$$

and the first derivative of this objective is

$$
(1 / 2) \frac{\partial \mathrm{J}_{0}}{\partial \mathrm{I}}-(1 / 2) \int_{0}^{\omega^{*}} \mathrm{R}_{1} \mathrm{f}(\omega) \mathrm{d} \omega-1
$$

If $\mathrm{I}_{0}$ is the investment that is optimal to the supplier of an unlevered firm then at $\mathrm{I}_{0}$,

$$
(1 / 2) \frac{\partial \mathrm{J}_{0}}{\partial \mathrm{I}}-1=0
$$

$\Rightarrow \quad$ The claim that supplier's investment is lowered with the firm's debt is proved by observing that (A2) is negative at $\mathrm{I}_{0}$. 


\section{Footnotes}

I thank N. K. Chidambaran, Hemang Desai, Noel Gaston, Jean Helwege, Sudha Krishnaswami, John Martin, Preston McAfee, Robert Parrino, Ramesh Rao, Alan Schwartz (the editor), Paul Spindt, two anonymous referees, and seminar participants at Texas A\&M, UT-Austin, and the 1995 FMA meetings for helpful comments and discussions. All errors remain my responsibility.

1 This is one of the key disadvantages of single sourcing documented in Lyons, Krachenberg, and Henke (1990). Supplier opportunism may also be in the form of the supplier renegotiating a contract with the firm's rival, thereby increasing bilateral profits at the firm's expense (McAfee and Schwartz, 1994).

2 Studies by Ruback and Zimmerman (1984), Voos and Mishel (1986), and Clark (1989) have estimated the cost of delay in the supply of inputs. In the context of labor supply, Ruback and Zimmerman find that when a labor union wins a representation election towards union formation, the equity value drops by about 3.8\%. In fact, these equityholders on average incur losses of $7.17 \%$ in the year prior to the petition of the election, indicating the investors' wariness of a potential bargaining problem in the future. In a study of non-labor inputs, Clark estimates that each day of delayed production in the automobile industry costs an average firm at least $\$ 1$ million.

3 The fundamental theme in Brander and Lewis (1986), Maksimovic (1988), and Rotemberg and Scharfstein (1990) is that debt financing enables the firm to credibly commit to an aggressive output stance in the product market, which is an advantage under Cournot competition. In our paper (as also in Bronars and Deere, 1991, and Perotti and Spier, 1993), debt is again a precommitment device, though not in the context of imperfect competition. Here, using debt precommits some of the future revenues of the 
firm to the debtholders, which proffers a bargaining advantage to the firm in its interactions with the labor union and other input suppliers.

4 This is also a benefit of debt in Dasgupta and Sengupta (1993). They model a firm and a labor union that jointly select effort, where investment mitigates the distortion in effort caused by debt.

5 Myers (1977) shows that when investment is made after the debt is issued, firms underinvest since the shareholders do not capture the entire return from the investment. This is because the cash inflows accrue only to the debtholders when the firm is insolvent, and so a part of the expected returns goes to the bondholders.

6 Evidence supporting the notion of proportional bankruptcy costs is in Altman (1983), Warner (1977), and Weiss (1990). It may however, be reasonable to assume that there are some fixed components to the administrative costs of bankruptcy. Therefore, to accurately reflect the total bankruptcy costs, we must impose an added cost of bankruptcy that represents the fixed costs faced by the firm. Thus our expected bankruptcy costs would be

$$
C\left(\omega^{*}\right)=\int_{0}^{\omega^{*}}\{c[D-R(I, \omega)]+K\} f(\omega) d \omega \text { where } 0<c<1 \text {, and } K>0 \text {. }
$$

Since this change does not alter any of our results, we use the simpler specification in (4). 7 Of course, in this stage, if the firm can costlessly switch to another supplier or to another set of workers then the hold-up problem does not arise. If the firm can switch suppliers, but only at a cost, then the status quo of the shareholders can be adjusted to reflect this, and the supplier's propensity to holdup the firm still exists.

8 An earlier version of the paper contained an infinite horizon bargaining game where the equilibrium payoffs to the firm and the supplier are identical to the Nash solution above. Directly using the Nash solution simplifies the exposition without changing the results. 
9 Considering only the case where $\rho=0$ simplifies the analysis without changing any of the main results. The propositions for the case $\rho>0$ are available from the author upon request.

10 Issuing riskless debt does not mitigate the underinvestment problem. If debt were riskless (i.e., $\mathrm{B}=\mathrm{D}$ ), which would be the case, say, if the debt for equity exchange were undertaken on date 1 after the demand uncertainty $\omega$ is resolved, then the equityholder objective is $\underset{\mathrm{I}}{\operatorname{Max}}(1 / 2)\left(\mathrm{J}_{0}-\mathrm{D}\right)+\mathrm{D}-\mathrm{I}$. Here debt shields wealth away from the supplier, but the optimal investment is still given by (16), and is too low.

11 If $\mathrm{D}$ were below $\rho \mathrm{I}$ or below $(1 / 2) \mathrm{J}_{0}$, then a threat by the firm-supplier alliance to liquidate would not be credible because the value lost from non-cooperation is greater for the firm-supplier alliance than for the debtholders. A formal proof of this result is in Appendix A of Hart and Moore (1994).

12 Also, in our paper debt is beneficial only because it mitigates underinvestment. This does not preclude the existence of other advantages of debt documented in Harris and Raviv (1991), that are not modeled here. Incorporating the tax benefits of debt will not affect our main results. Also, the signaling benefit of debt (Ross, 1977) does not apply here because we do not model information asymmetry between the managers and the outside investors of the firm. In a world where managers derive private benefits of control, debt mitigates the free cash flow problem (Jensen, 1986), and also increases alignment of managerial incentives with those of the shareholders (Jensen and Meckling, 1976). Again, since we do not model the manager-shareholder problem, these benefits do not arise in our analysis.

13 In proposition 4 we show that if it is the supplier and not the firm that makes the investment, then an increase in the firm's debt exacerbates underinvestment. Therefore, a study that tests the predictions of our model by analyzing the correlation between debt 
levels and investment should control for which of the two parties, the firm or the supplier, makes the investment.

14 In Shleifer and Summers (1988) breach of contract and the associated wealth transfer is driven by the change in management (that usually follows a takeover or a leveraged buyout), while in our paper it is a result of the increased debt. Thus our model would predict that wealth transfers should arise even in buyouts where the current management buys the firm (MBOs), and in those LBOs where there is no management turnover.

15 While we recognize that it is questionable to generalize based on anecdotal evidence, we are not aware of a direct empirical study on the wealth effects of LBOs on suppliers' shareholders.

16 Ravenscraft and Scherer (1987) provide several examples of mergers where the latent problems with the target elude the buyer's pre-merger inspections. For example, Wickes Inc. discovered that its recently acquired carpet manufacturing subsidiary, Collins \& Aikman, had potential product liabilities arising from violations of federal flammability standards for carpets. The estimated costs associated with this oversight exceeded $20 \%$ of the purchase price of Collins \& Aikman. 


\section{References}

Acs, Zoltan, Steven Isberg, and David Levy. 1993. "Industry Concentration, Asset Specificity, and Capital Structure: An Empirical Analysis," University of Baltimore working paper.

Altman, Edward. 1983. A Complete Guide to Predicting, Avoiding, and Dealing with Bankruptcy. New York: John Wiley \& Sons.

Aron, Debra. 1991. "Using the Capital Market as a Monitor: Corporate Spinoffs in an Agency Framework," 22 RAND Journal of Economics 505-518.

Baker, George, and Karen Wruck. 1989. “Organizational Changes and Value Creation in Leveraged Buy-outs: The Case of O.M.Scott \& Sons Company,” 25 Journal of Financial Economics 163-190.

Baldwin, Carliss. 1983. "Productivity and Labor Unions: An Application of the Theory of Self-enforcing Contracts," 56 Journal of Business 155-186.

Berger, Philip, and Eli Ofek. 1995. "Diversification's Effect on Firm Value," 37 Journal of Financial Economics 39-65.

Berglof, Erik, and Ernst-Ludwig von Thadden. 1994. "Short-term versus Long-term Interests: Capital Structure with Multiple Investors," 109 Quarterly Journal of Economics 1055-1084.

Berkovitch, Elazar, E. Han Kim. 1990. "Financial Contracting and Leverage Induced Over- and Under-Investment Incentives, 45 Journal of Finance 765-794.

Bradley, Michael, Anand Desai, and E. Han Kim. 1988. "Synergistic Gains from Corporate Acquisitions and Their Division Between the Stockholders of Target and Acquiring Firms," 21 Journal of Financial Economics 3-40.

Brander, James, and Tracy Lewis. 1986. “Oligopoly and Financial Structure: The Limited Liability Effect," 76 American Economic Review 956-970. 
Bronars, Stephen G., and Donald R. Deere. 1991. "The Threat of Unionization, the Use of Debt, and the Preservation of Equityholder Wealth," 106 Quarterly Journal of Economics 231-254.

Clark, Kim. 1989. "Project Scope and Project Performance: The Effects of Parts Strategy and Supplier Involvement on Product Development," 35 Management Science 1247-1263.

Dasgupta, Sudipto, and Kunal Sengupta. 1993. "Sunk Investment, Bargaining, and the Choice of Capital Structure," 34 International Economic Review 203-220.

Edlin, Aaron, and Stefan Reichelstein. 1996. "Holdups, Standard Breach Remedies, and Optimal Investment," American Economic Review (forthcoming).

Garvey, Gerald T., and Noel G. Gaston. 1995. "Getting Tough with Workers? Evidence from the Strategic Role of Debt," Tulane University working paper.

Grout, Paul. 1984. "Investment and Wages in the Absence of Binding Contracts: A Nash Bargaining Approach,” 42 Econometrica 449-460.

Harris, F. 1994. “Asset Specificity, Capital Intensity, and Capital Structure: An Empirical Test," 15 Managerial and Decision Economics 563-576.

Harris, Milton, and Artur Raviv. 1991. "Theory of Capital Structure," 46 Journal of Finance 297-356.

Hart, Oliver, and John Moore. 1994. "A Theory of Debt Based on the Inalienability of Human Capital," 109 Quarterly Journal of Economics 841-879.

Helper, Susan, and David Levine. 1992. "Long-Term Supplier Relations and ProductMarket Structure," 8 Journal of Law Economics and Organization 561 - 581.

Hermalin, Benjamin, and Michael Katz. 1993. "Judicial Modification of Contracts Between Sophisticated Parties: A More Complete View of Incomplete Contracts and their Breach," 9 Journal of Law Economics and Organization 230-255. 
Jensen, Michael. 1986. “Agency Costs of Free Cash Flow, Corporate Finance, and the Market for Takeovers," 76 American Economic Review 323-329. . and William Meckling. 1976. "Theory of the Firm: Managerial Behavior, Agency Costs, and Ownership Structure," 3 Journal of Financial Economics 305360.

Joskow, Paul. 1985. "Vertical Integration and Long-Term Contracts," 1 Journal of Law, Economics and Organization 33 -80.

Kleindorfer, Paul, and G. Knieps. 1982. "Vertical Integration and Transaction Specific Sunk Costs," 19 European Economic Review 71 - 87.

Lyons, Thomas, A. Richard Krachenberg, and John W. Henke. 1990. "Mixed Motive Marriages: What's Next for Buyer-Supplier Relations," 29 Sloan Management Review 29-36.

Maksimovic, Vojislav. 1988. "Capital Structure in Repeated Oligopolies," 19 RAND Journal of Economics 389-407.

McAfee, Preston, and Marius Schwartz. 1994. “Opportunism in Multilateral Vertical Contracting: Nondiscrimination, Exclusivity, and Uniformity," 84 American Economic Review 210-30.

Milgrom, Paul, and John Roberts. 1992. Economics, Organization and Management. Englewood Cliffs, NJ: Prentice Hall.

Myers, Stewart. 1977. "Determinants of Corporate Borrowing," 4 Journal of Financial Economics 147-175.

Nash, John. 1953. “Two Person Cooperative Games,” 21 Econometrica 97-109.

Perotti, Enrico, and Kathryn Spier. 1993. "Capital Structure as a Bargaining Tool: The Role of Leverage in Contract Renegotiation," 83 American Economic Review 1131-1141. 
Ravenscraft, David, and Frederic M. Scherer. 1987. “Mergers, Sell-offs, and Economic Efficiency," Washington, D.C.: Brookings Institution.

Riordan, Michael. 1989. "What is Vertical Integration?" in M. Aoki, B. Gustafsson, and O. Williamson, eds., The Firm as a Nexus of Treaties. London: Sage.

Ross, Stephen. 1977, “The Determination of Financial Structure: The Incentive Signaling Approach," 8 Bell Journal of Economics 23-40.

Rotemberg, Julio, and David Scharfstein. 1990. "Shareholder-Value Maximization and Product Market Competition,” 3 Review of Financial Studies 367-391.

Ruback, Richard, and Martin Zimmerman. 1984. "Unionization and Profitability: Evidence from the Capital Market," 42 Journal of Political Economy 1134-1157. Rubinstein, Ariel. 1982. "Perfect Equilibrium in a Bargaining Model," 50 Econometrica 97-109.

Schiller, Zachary. 1987. "Merger Phobia Has Unions Wheeling and Dealing," Business Week, March 23, 118-120.

Selten, Reinhard. 1975. "Reexamination of the Perfectness Concept for Equilibrium Points in Extensive Games," 4 International Journal of Game Theory 25-55.

Shleifer, Andrei, and Lawrence Summers. 1988. "Hostile Takeovers and Breach of Trust," in Alan J. Auerbach, eds., Corporate Takeovers: Causes and Consequences. Chicago: University of Chicago Press.

Sutton, John. 1986. “Non-Cooperative Bargaining Theory: An Introduction," Review of Economic Studies 709-724.

Tirole, Jean. 1990. The Theory of Industrial Organization. Cambridge: MIT Press. Voos, Paula, and Lawrence Mishel. 1986. “The Union Impact on Profits: Evidence from Industry Price-Cost Margin Data," 4 Journal of Labor Economics 105-133.

Warner, Jerold. 1977. "Bankruptcy Costs: Some Evidence," 32 Journal of Finance 337347. 
Weiss, Lawrence. 1990. “Bankruptcy Dissolution: Direct Costs and Violation of Priority and Claims," 22 Journal of Financial Economics 285-314.

Wiggins, Steven. 1990. “The Comparative Advantage of Long-term Contracts and Firms," 6 Journal of Law, Economics and Organization 155-170.

Williamson, Oliver. 1975. Markets and Hierarchies: Analysis and Anti-trust Implications. New York: The Free Press. . 1985. The Economic Institutions of Capitalism: Firms, Markets, Relational Contracting. New York: The Free Press. 